seem that clinical assessment of myocardial infarction patients at 48 hours is a reliable means of selecting the uncomplicated cases and that immediate mobilization of these patients is not associated with any increase in mortality.

Similar problems arise when comparing morbidity figures from the different trials. Our study was mainly concerned with the short-term problems that were most likely to relate to the duration of bed rest. As might be expected the incidence of complications fell with increasing time from the onset of the myocardial infarction. From the end of the second week to six weeks after the date of infarction our total morbidity, including death, readmission to hospital, or the development of complications restricting activities, was $5.7 \%$ in the early mobilization group and $6.6 \%$ in the late mobilization group. Harpur et al. (1971) found $7 \cdot 7 \%$ in the early and $7.4 \%$ in the late group developed such complications over a similar period.

We were particularly interested to know whether the period of bed rest affected the development of deep venous thrombosis. A positive ${ }^{125}$ I-labelled fibrinogen calf scan occurred in $18 \%$ of the patients mobilized early and in $16 \%$ of those mobilized late. This incidence is similar to the findings of Warlow et al. (1973) but considerably lower than that of earlier authors (Maurer et al., 1971; Simmons et al., 1973). A more detailed report of these figures is being prepared, but it does seem that bed rest of the duration used in this study does not affect the incidence of deep venous thrombosis detected either clinically or by ${ }^{125}$ I-labelled fibrinogen scanning. The incidence of both clinical deep venous thrombosis and pulmonary embolus was low in both groups and did not contribute to the mortality in either group.

The short duration of hospital stay in both groups was not associated with a significant increase in readmissions. Of the 10 patients readmitted, four had already been removed from the study because of complications within the first nine days of their admission to hospital.

After discharge from hospital all patients were told to increase their activities progressively. At the outpatient visit six weeks after their hospital admission we did not detect any lack of willingness on the part of the patients, their relatives, or their family doctors to follow this advice. Over $90 \%$ of the patients were ready to return to work but before doing so were awaiting instructions from the hospital physicians.

A policy of early discharge from hospital is probably beneficial to the patient from a psychological point of view (Levine and Lown, 1952). It is undoubtedly of value to a busy general hospital which is short of beds for acutely ill medical patients. It seems that most patients who seem well at 48 hours after the onset of the symptoms of a myocardial infarction need no further treatment and possibly could be discharged from hospital. Nevertheless, $18 \%$ of our patients either died or developed a complication needing treatment during the first nine days of their illness, even though they had been apparently well after the first 48 hours. Therefore, unless it is possible to identify the patients who will develop complications it seems that the period of hospital stay cannot be shortened much further. Various methods of selecting the high risk patients have been described (Norris et al., 1969; Wilson and Pantridge, 1973), and we are continuing to study this problem.

We thank Professor J. R. A. Mitchell, Dr. S. Allison. Dr. M. Knapp, Dr. P. J. Toghill, and Dr. M. V. Wells for their help. We are also grateful for the co-operation of the junior hospital staff and the nursing staff of the coronary care unit and the medical wards of Nottingham General Hospital and for the skilled technical help of Mrs. E. Holland. The contents of this paper were presented to the British Cardiac Society in December 1973.

\section{References}

Fulton, M., Julian, D. G., and Oliver, M. F. (1969). Circulation, Supplements, 39-40, No. IV, p. 182.

Gibbs, N. M. (1957). British fournal of Surgery, 45, 209

Groden, B. M., Allison, A., and Shaw, G. B. (1967). Scottish Medical fournal, $12,435$.

Harpur, J. E., et al. (1971). Lancet, 2, 1331.

Hutter, A. M., et al. (1973). New England fournal of Medicine, 288, 1141. evine, S. A., and Lown, B. (1952). Journal of the American Medical Associa tion, 148, 1365 .

Maurer, B. J., Wray, R., and Shillingford, J. P. (1971). Lancet, 2, 1385.

Medical Division, Royal Infirmary, Glasgow. (1973). Lancet, 2, 346.

Norris, R. M., et al. (1969). Lancet, 1, 274.

Simmons, A. V., Sheppard, M. A., and Cox, A. F. (1973). British Heart fournal, 35, 623 .

Spracklen, F. H. N., et al. (1968). British Medical fournal, 4, 364

Takkunen, J., et al. (1970). Acta Medica Scandinavica, 188, 103.

Warlow, C., et al. (1973). Lancet, $2,934$.

Wilson, C., and Pantridge, J. F. (1973). Lancet, 2, 1284.

\title{
Ward Design in Relation to Postoperative Wound Infection: Part III
}

\author{
G. SMITH， J. R. C. LOGIE， A. MACDONALD， H. G. SMYLIE
}

British Medical fournal, 1974, 3, 13-15

\section{Summary}

The wound infection rates, nasal carriage rates, and nasal colonization rates were studied in a recently built surgical unit for two years when it was first opened. Five years later a further two-year period of study was undertaken.

Judging by the incidence of postoperative wound infection, as far as both Staphylococcus pyogenes and Gram-negative

University of Aberdeen, Aberdeen AB9 2ZD

G. SMITH, CH.M., F.R.C.s., Regius Professor of Surgery

J. R. C. LOGIE, M.B., CH.B., Lecturer in Surgery

A. MACDONALD, M.A., M.D., Professor of Bacteriology

H. G. SMYLIE, M.D., M.R.C.PATH., Senior Lecturer in Bacteriology organisms are concerned, there is no evidence that the environment has become less safe with use over the seven-year period since opening.

\section{Introducton}

In 1971 we published the results of a study of the effect of ward design on postoperative wound infection (Smylie et al., 1971; Davidson et al., 1971 a). This study was based on the epidemiology of wound infection during the period October 1964 to September 1966, when the professorial surgical unit occupied two "Nightingale"-type wards, and during a similar two-year period from October 1966 to September 1968, when a new "race track" ward of similar size was used.

While the improvement in postoperative wound infection rates was striking it was necessary to bear in mind that the 
improvement might have been attributable, in part at least, to the change to new buildings and that the specially designed ventilation system and highly compartmented nature of the accommodation might in time prove to be less effective and the ameliorating benefits diminished by continued use.

We have therefore extended the study and now record the results obtained during the period October 1971 to September 1973 (period 2) and compare them with those found during 1966-8 (period 1), when the unit first occupied its new quarters. The members of staff at consultant and senior nursing level were the same in both periods, and the work load and spectrum of surgical conditions treated were also similar during the two periods. Details of the collection of bacterial samples and their processing have been described previously (Davidson et al., 1971 a, b; Smylie et al., 1971). It may be worthwhile to state again the descriptions used of the various categories of wound infection. Two grades were recorded: the major indicated severe sepsis with pus formation requiring drainage and frequent dressings, which caused the patient's stay in hospital to be prolonged beyond that which would have been expected; minor sepsis existed where pus formation was slight or there was a transient cellulitis of the wound area or a stitoh abscess without any increase in morbidity. In either group the cultivation of pathogens from the discharge was possible during period 1 . In period 2, however, a few of the wounds were noted as obviously belonging clinically to the minor category, from which no growth of bacteria was obtained. These are recorded in the tables.

\section{Nasal Carriage of Staphylococcus pyogenes}

During the present survey (period 2) we found that of the 1,018 patients studied on admission to the unit $228(22.4 \%)$ were nasal carriers of Staphylococcus pyogenes. In period 1 out of 2,372 patients the corresponding nasal carriage rate was $24.3 \%$ During period $227.2 \%$ carried penicillin insensitive stains while for period 1 the corresponding figure was $21.9 \%$. These figures are of the order found in 1964-5 among patients on admission to the same unit. The increased carriage rate of penicillin insensitive organisms would, if anything, have tended to affect adversely the ward environment during the period of this study, assuming the virulence of such penicillin insensitive organisms to be at the same level throughout-an assumption by no means justifiable, as will be indicated later.

During period 1 half the patients acquiring nasal carriage of staphylococci in hospital had done so by the end of the first week. Results in period 2 were similar. Of all the patients $1.9 \%$ acquired nasal colonization of penicillin-insensitive staphylococci during their stay in hospital in period 1, and $2.5 \%$ did so in period 2 .

In a separate study carried out during period 2 the relation of nasal carriage to subsequent wound infection by $S$. pyogenes was studied in 570 patients. A total of 120 had the organism in their noses at time of operation and $13(10.8 \%)$ of these developed a postoperative wound infection from which $S$. pyogenes was isolated. In eight of the 13 cases the organism had the same antibiogram as that of their original nasal isolate. In the 450 non-carriers postoperative staphylococcal wound infection occurred in 11 patients $(2 \cdot 4 \%)$.

In a previous study which included period 1 (Davidson et al., 1971 b) it was noted that staphylococcal wound infection occurred in 15 out of 120 patients $(12.5 \%)$ who were nasal carriers of $S$. pyogenes. In 683 non-carriers postoperative staphylococcal wound infection occurred in $49(7 \cdot 2 \%)$.

During period 2 nasal swabs were examined at intervals from members of the relevant surgical and nursing staff and $24 \%$ were found to be carriers of $S$. pyogenes. Of 18 positive swabs cultured $15(83 \%)$ were found to be penicillin insensitive. Though these numbers are very small the results are similar to those found in the similar investigation of the staff during period 1 (Smylie et al., 1971).

It thus seems that despite more patients coming into hospital with $S$. pyogenes in their noses less infection of postoperative wounds occurred both in the nasal carriers and in the non-carriers, the change being especially marked in the latter group.

\section{Rates of Wound Infection}

The gross figures for wound infections of whatever degree were derived from 1,737 and 1,799 wounds studied during periods 1 and 2 respectively. The respective percentages of infected wounds were $14.9 \%$ and $11 \cdot 1 \%$. Using the grouping of wound infections previously suggested as descriptive of cross-infection sources (Smylie et al., 1971) it seemed that the rate of $S$. pyogenes cross-infection of surgical wounds was $3.3 \%$ and $1.3 \%$ in periods 1 and 2 respectively. In period 2 53 wounds were infected by $S$. pyogenes, 33 of which were penicillin insensitive. Twenty-three instances of wound infection thought to be attributable to cross-infection were detected, and of these six were considered to be major infections. No deaths occurred from staphylococcal sepsis.

Further categorization into groups previously used (Davidson et al., 1971 a) allowed comparisons to be made between the outcome of 507 and 1,799 wounds studied during periods 1 and 2 respectively (table $I$ ).

The $S$. pvogenes wound infection rates were $4.9 \%$ in period 1 and $2.9 \%$ in period 2, a major infection occurring in $2.0 \%$ and $0.5 \%$ respectively. This trend towards a lowered staphylococcal infection rate in all categories bears out the impression that cross infection was being controlled at least as well during period 2 as during 1 . From a consideration of the marked diminution in the rate of maior staphylococcal infection in period 2 it is possible that the virulence of this organism might have been lower than previously.

Classifying staphylococcal infections into primary and secondary types as suggested previously (Davidson et al., 1971 a), the primary infection rates for clean wounds were $1.4 \%$ in period 1 and $1.2 \%$ in period 2 , while for potentially dirty wounds the figures were $0.7 \%$ and $1.2 \%$ respectively. For secondary infection rates the figures were $1.7 \%$ in period 1 and $1.0 \%$ in period 2 for clean operations and $8.6 \%$ and

TABLB I-Incidence of Wound Infection in Surgical Ward during Two Two-year Periods

\begin{tabular}{|c|c|c|c|c|c|c|c|c|}
\hline & \multirow{2}{*}{$\begin{array}{l}\text { No. of } \\
\text { Patients }\end{array}$} & \multirow{2}{*}{$\begin{array}{c}\text { Total } \\
\text { Infected } \\
\text { Wounds }\end{array}$} & \multicolumn{2}{|c|}{ Staphylococcal } & \multicolumn{2}{|c|}{ Intestinal } & \multicolumn{2}{|c|}{ No Growth } \\
\hline & & & All & Major & All & Major & All & Major \\
\hline $\begin{array}{l}\text { Gross rates: } \\
\text { Period } 1 \\
\text { Period } 2\end{array}$ & $\begin{array}{r}507 \\
1,799\end{array}$ & $\begin{array}{c}49(9 \cdot 7 \%) \\
199 *(11 \cdot 1 \%)\end{array}$ & $\begin{array}{l}25(4.9 \%) \\
53(2.9 \%)\end{array}$ & $\begin{array}{r}10(2.0 \%) \\
9(0.5 \%)\end{array}$ & $\begin{array}{r}24(4.7 \%) \\
124(6.9 \%)\end{array}$ & $\begin{array}{l}15(3.0 \%) \\
37(2 \cdot 1 \%)\end{array}$ & $28 \overline{(1.6 \%)}$ & $2 \overline{(0.1 \%)}$ \\
\hline $\begin{array}{l}\text { Clean operations: } \\
\text { Period } 1 \\
\text { Period } 2\end{array}$ & $\begin{array}{l}355 \\
969\end{array}$ & $\begin{array}{l}19(5.4 \%) \\
54(5.6 \%)\end{array}$ & $\begin{array}{l}11(3.1 \%) \\
22(2.3 \%)\end{array}$ & $\begin{array}{l}5(1.4 \%) \\
2(0.2 \%)\end{array}$ & $\begin{array}{r}8(2 \cdot 3 \%) \\
19(2 \cdot 0 \%)\end{array}$ & $\begin{array}{l}5(1.4 \%) \\
3(0.3 \%)\end{array}$ & $15 \overline{(1.5 \%)}$ & $1 \overline{(0.1} \%)$ \\
\hline $\begin{array}{l}\text { Potentially dirty operations: } \\
\text { Period } 1 \\
\text { Period } 2\end{array}$ & $\begin{array}{l}152 \\
830\end{array}$ & $\begin{aligned} 30 & (19 \cdot 7 \%) \\
145 & (17.5 \%)\end{aligned}$ & $\begin{array}{l}14(9 \cdot 2 \%) \\
31(3.7 \%)\end{array}$ & $\begin{array}{l}5(3.3 \%) \\
7(0.8 \%)\end{array}$ & $\begin{array}{r}16(10.5 \%) \\
105(12.7 \%)\end{array}$ & $\begin{array}{l}10(6.6 \%) \\
33(4.0 \%)\end{array}$ & $13 \overline{(1 \cdot 6 \%)}$ & $1 \overline{(0.1} \%)$ \\
\hline
\end{tabular}

- Six cases had both staphylococcal and intestinal organisms present in their wounds. Four of these double infections occurred in potentially dirty cases and two occurred in clean wounds. 
TABLE IV-Incidence of injecion in Wounds Drained and not Drained in Two Periods

\begin{tabular}{|c|c|c|c|c|}
\hline & \multicolumn{2}{|c|}{ Staphylococcal Infections } & \multicolumn{2}{|c|}{ Intestinal Organism Infections } \\
\hline & Period 1 & Period 2 & Period 1 & Period 2 \\
\hline Clean operations $\left\{\begin{array}{l}\text { Not Drained } \\
\text { Drained } \\
\text { Pot Drained } \\
\text { Drained }\end{array}\right.$ & $\begin{array}{l}6 / 303(2 \cdot 0 \%) \\
5 / 52(9.6 \%) \\
4 / 47(8.5 \%) \\
10 / 105(9.5 \%)\end{array}$ & $\begin{array}{ll}12 / 766 & (1 \cdot 6 \%) \\
10 / 203 & (4 \cdot 9 \%) \\
11 / 432 & (2.5 \%) \\
20 / 398 & (5 \cdot 0 \%)\end{array}$ & $\begin{array}{c}6 / 303(2 \cdot 0 \%) \\
2 / 52(3.9 \%) \\
4 / 47(8.5 \%) \\
12 / 105(11.5 \%)\end{array}$ & $\begin{aligned} 14 / 766 & (1.8 \%) \\
5 / 203 & (2.5 \%) \\
30 / 432 & (6.9 \%) \\
75 / 398 & (18.8 \%)\end{aligned}$ \\
\hline Total & $25 / 507(4.9 \%)$ & $53 / 1799(2.9 \%)$ & $24 / 507(4 \cdot 8 \%)$ & $124 / 1799(6.9 \%)$ \\
\hline
\end{tabular}

$2.5 \%$ respectively for potentially dirty operations (table II).

Taken in conjunction with the findings on nasal carriage rate and acquisition rate of penicillin insensitive organisms, as far as infection of surgical wounds by $S$. pyogenes is concerned, there is no evidence that the new environment has in any way deteriorated since the epidemiological survey carried out in 1966-8.

TABLE II-Incidence of Primary and Secondary Staphylococcal Infections during Two Periods

\begin{tabular}{|c|c|c|c|}
\hline & Type of Operation & Period 1 & Period 2 \\
\hline \multirow[t]{2}{*}{ Primary \{} & $\begin{array}{l}\text { Clean } \\
\text { Potentially Dirty }\end{array}$ & $\begin{array}{l}5(1.4 \%) \\
1(0.7 \%)\end{array}$ & $\begin{array}{l}12(1 \cdot 2 \%) \\
10(1.2 \%)\end{array}$ \\
\hline & Total & $6(1 \cdot 2 \%)$ & $22\left(1 \cdot 2^{\prime}{ }_{0}\right)$ \\
\hline \multirow[t]{2}{*}{ Secondary \{} & $\begin{array}{l}\text { Clean } \\
\text { Potentially Dirty }\end{array}$ & $\begin{array}{r}6\left(1 \cdot 7^{\circ}\right) \\
13\left(8 \cdot 6^{\circ} \%\right)\end{array}$ & $\begin{array}{l}10\left(1 \cdot 0^{\circ}{ }_{0}\right) \\
21\left(2 \cdot{ }^{\circ}{ }_{0}\right)\end{array}$ \\
\hline & Total & $19(3.7 \%)$ & $31(1.7 \%)$ \\
\hline
\end{tabular}

\section{Wound Infections by Gram-negative Organisms}

The epidemiology of infections due to various intestinal organisms is made difficult by the lack of easy typing techniques. Recourse has been had to the use of antibiotic sensitivities in attempting to assess the spread of thuse organisms among patients, but this has had only limited success.

In both clean and sotentially dirty operations the rates of wound infections did not differ greatly in periods 1 and 2, being respectively $2.3 \%$ and $2.0 \%$ for clean operations and $10.5 \%$ and $12.7 \%$ for the potentially infected group. Considering only major infections these figures become $1.4 \%$ and $0.3 \%$ and $6.6 \%$ and $4.0 \%$ respectively (see table I).

To take this analysis further the postoperative infections by intestinal organisms were divided into those following emergency surgery and those following elective surgery. Using figures obtained in a previous investigation by Davidson et al. (1971 c) and collected during four years before period 2 the infection rate was $19.3 \%$ for emergencies and $6.4 \%$ for elective operations. In period 2 the respective figures were $13.7 \%$ and $5.7 \%$. The corresponding staphylococcal rates were $5.5 \%$ in the earlier period and $3.2 \%$ in period 2 for elective surgery while for emergency cases the figures were 6.8 and $2.9 \%$ respectively. The Gram-negative infections in these emergency cases were in the main primary. These figures did not reflect any deterioration in the environment either at theatre or ward level (table III).

Another clue can be obtained by studying the outcome of wounds in the clean and the potentially dirty group into which
TABLE III-Incidence of Wound Infection in Emergency Cases and in Patients undergoing Elective Surgery during Two Periods

\begin{tabular}{|c|c|c|c|c|}
\hline & \multirow{2}{*}{$\begin{array}{l}\text { No. of } \\
\text { Cases }\end{array}$} & \multirow{2}{*}{$\begin{array}{c}\text { Total } \\
\text { Infected }\end{array}$} & \multicolumn{2}{|c|}{ Organisms } \\
\hline & & & $\overline{\text { Staphylococcal }}$ & Intestinal \\
\hline $\begin{array}{l}\text { Period 1964-8: } \\
\text { Emergency } \\
\text { Elective } \\
\text { Period 2: }\end{array}$ & $\begin{array}{l}109 \\
891\end{array}$ & $\begin{array}{r}27(24 \cdot 8 \%) \\
118(13 \cdot 2 \%)\end{array}$ & $\begin{array}{r}6(5 \cdot 5 \%) \\
61(6 \cdot 8 \%)\end{array}$ & $\begin{array}{ll}21 & (19.3 \%) \\
57 & (6.4 \%)\end{array}$ \\
\hline $\begin{array}{l}\text { Emergency } \\
\text { Elective }\end{array}$ & $\begin{array}{r}277 \\
1,522\end{array}$ & $\begin{array}{c}48(17 \cdot 3 \%) \\
151(9.9 \%)\end{array}$ & $\begin{array}{r}9(3.2 \%) \\
44(2.9 \%)\end{array}$ & $\begin{array}{l}38 *(13 \cdot 7 \%) \\
86+(5 \cdot 7 \%)\end{array}$ \\
\hline
\end{tabular}

*No growth occurred in two cases and double infection occurred in one. $\dagger$ No growth occurred in 26 cases and double infection occurred in five.

drains were inserted. Thus in period 1 clean wounds not drained had an infection rate by intestinal organisms of $2.0 \%$ and in period 2 of $1.8 \%$, while clean and drained wounds showed rates of $3.9 \%$ and $2.5 \%$ for period 1 and 2 respectively. These were made up mainly of secondarily infected wounds and as such suggested that no increase in the environmental hazards due to Gram-negative organisms had taken place (table IV).

The wound infection rates for this class of organism were also examined for relation to age of patient, length of operation, and type of operation, with special reference to those potentially dirty operations in the abdomen. They were also examined according to the individual members of the surgical unit carrying out the operations. Suffice it to say that while highly interesting interrelations became obvious in and between these subcategories there was no evidence discernible which indicated that the environment had become less safe from the point of view of postoperative wound infection over the period of seven years during which it has been studied. There are no grounds for complacency, and indeed complacency can never exist in such a manual exercise as the craft of surgery. It is clear, nevertheless, that this particular design for a surgical unit, which was found to diminish the risk of cross-infection (Davidson et al., 1971 a; Smylie et al., 1971) shows no evidence of losing this effect through familiarity and constant usage over the past seven years.

This study was supported by a grant to G.S. from S.H.E.R.T.

\section{References}

Davidson, A. I. G., Smylie, H. G., Macdonald, A., and Smith, G. (1971 a) British Medical fournal, 1, 72

Davidson, A. I. G., Smith, G., and Smylie, H. G. (1917 b). British fournal of Surgery, 58, 326

Davidson, A. I. G., Clark, C., and Smith, G. (1971 c). British fournal of Surgery, 58, 333

Smylie, H. G., Davidson, A. I. G., Macdonald, A., and Smith, G. (1971). British Medical fournal, 1, 67. 